\title{
Penerapan Teori Belajar Kognitif Pada Mata Pelajaran PAI Tingkat SMP di SIT Bina Insan Batang Kuis
}

\author{
Muhammad Alpin Hascan ${ }^{1}$, Suyadi ${ }^{2}$ \\ ${ }^{1}$ (Pendidikan Agama Islam, Pascasarjana/UIN Sunan Kalijaga Yogyakarta) \\ 2 (Pendidikan Agama Islam, Pascasarjana/UIN Sunan Kalijaga Yogyakarta) \\ * Corresponding Author. E-mail: ${ }^{1}$ 19204010125@student.uin-suka.ac.id \\ ²suyadi@uin-suka.ac.id
}

Receive: 13/05/2021

Accepted: 23/08/2021

Published: 01/10/2021

\begin{abstract}
Abstrak
Teori belajar dalam dunia pendidikan banyak jumlahnya, salah satu yang sering dan lazim digunakan khususnya di Indonesia adalah teori belajar kognitif. Teori tersebut merupakan satu diantara teori-teori lain yang cukup efektif dalam aplikasinya. Penelitian ini bertujuan untuk mengkaji bagaimana penerapan teori belajar kognitif pada mata pelajaran PAI tingkat SMP di Sekolah Islam Terpadu Bina Insan Batang Kuis. Penelitian ini menggunakan pendekatan kualitatif deskriptif yang dikaji melalui studi pustaka yaitu analisis buku dan penelitian-penelitian ilmiah. Hasil penelitian ini menunjukkan bahwa teori belajar kognitif efektif untuk diterapkan di sekolah SDIT Bina Insan tingkat SMP pada mata pelajaran PAI. Efektivitas tersebut harus didukung dengan kreativitas pendidik dengan menggunakan serta mengkolaborasikan strategi, metode dan media pembelajaran agar teori belajar kognitif dapat diaplikasikan sesuai dengan harapan namun tetap juga memperhatikan hal-hal yang menjadi kelemahan teori kognitif agar bisa ditangani dengan baik sehingga pembelajaran dapat berjalan dengan sempurna.
\end{abstract}

Kata kunci: Teori, Kognitif, Aplikasi, Pembelajaran

Application of Cognitive Learning Theory in JUNIOR LEVEL for PAI Subjects in SIT Bina Insan Batang Kuis

Abstract

Learning theory in the world of education is many, one that is often and commonly used, especially in Indonesia is the theory of cognitive learning. This theory is one of the other theories that is quite effective in its application. This research aims to examine how the application of cognitive learning theory in pai subjects at the junior level pai at the Integrated Islamic School Bina Insan Batang Kuis. This research uses a descriptive qualitative approach that is studied through literature studies, namely book analysis and scientific research. The results of this study show that cognitive learning theory is effective to be applied in junior high school in PAl subjects. This effectiveness must be supported by the creativity of educators by using and collaborating strategies, methods and learning media so that cognitive learning theory can be applied in accordance with expectations but still also pay attention to the things that are the weaknesses of the theory of learning.

Keywords: Theory, Cognitivism, Applications, Learning 


\section{Pendahuluan}

Belajar merupakan suatu proses yang terarah kepada perolehan tujuan tertentu terhadap berbagai situasi yang ada disekeliling individu peserta didik melalui beraneka ragam pengalaman yang tercipta saat proses pembelajaran berlangsung. (Rusman, 2017, p. 75). Dikatakan suatu proses belajar terjadi apabila terbentuknya interaksi antara seseorang dengan lingkungannya. Seseorang merasakan perubahan tingkah laku pada dirinya ketika ia telah belajar, perubahan tersebut berupa pengetahuan dan keterampilan baru baik berbentuk sikap ataupun value yang positif. Menurut kognitif belajar sebagai suatu proses pembentukan persepsi individu terhadap fenomena yang tampak. Oleh karenanya menurut teori ini belajar lebih mengutamakan proses dari pada hasil. Untuk dapat melalui proses belajar terdapat tiga potensi yang harus diubah, yaitu potensi intelektual (kognitif), potensi moral kepribadian (afektif) dan keterampilan mekanik/otot (psikomotorik). (Zainal dan Ahmad, 2019, p. 1-2). Kecerdasan dan pengetahuan mempunyai keterkaitan yang erat. Dua hal tersebut bukan sebagai kuantitas atau sesuatu hal yang statis. Kecerdasan bagian dari dinamis serta aktif dan selalu mengalami perubahan, sedangakan pengetahuan merupakan suatu hal yang harus diketahui sebagai sebuah proses yang diwujudkan melalui aktivitas pembelajar. (Wayan, 2017, p. 41).

Dalam dunia pendidikan ada beberapa teori belajar yang digunakan, masing-masing dari teori memiliki prinsip serta konsep yang berbeda. Teori belajar sebagai cara untuk dapat menggambarkan bagaimana seseorang itu belajar, sehingga meringankan si pembelajar terhadap pemahaman proses inheren yang kompleks dari belajar. Teori belajar dimaknai sebagai konsep-konsep dan prinsip-prinsip belajar yang bersifat teoritis dan telah diuji kebenarannya melalui eksperimen. (Tutik dan Daryanto, 2015, p. 36). Sebagaimana yang penulis kutip dari penelitian
Rifqiyyatush Sholihah Al-Mahiroh dan Suyadi bahwa ada beberapa teori belajar yang relevan untuk diaplikasikan dalam proses pembelajaran, diantaranya adalah: 1) teori belajar humanisme, yaitu proses belajar yang dilakukan untuk memanusiakan manusia dengan tercapainya aktualisasi diri pada siswa secara optimal; 2) teori belajar konstruktivisme, yaitu penataan pengetahuan dari pengalaman konkret, aktif dalam bekerja sama, refleksi serta interpretasi; 3) teori belajar sibernetik, yaitu proses belajar dengan mengolah informasi (pesan pembelajaran) yang ditentukan oleh system informasi kemudian; dan 4) teori belajar kognitif, yakni pengorganisasian aspek kognitif dan persepsi dalam mewujudkan suatu pemahaman. (Rifqiyyatush dan Suyadi, 2020, p. 118). Relevansi dari teori-teori belajar tersebut dapat berhasil karena persiapkan pendidik yang matang sebagai upaya mengaplikasikan teori tersebut. Pendidik harus terlebih dahulu mengetahui apa saja yang harus ia persiapkan dalam menghadapai peserta didiknya dengan mempersiapkan strategi, metode serta media yang mendukung agar teori belajar dapat diterapkan sebagaimana mestinya disesuaikan dengan materi serta kondisi peserta didik.

Untuk mencapai kesuksesan dalam proses belajar mengajar tentunya pendidik mempunyai tugas untuk menyiapkan beberapa persiapan untuk mengajar, seperti materi, metode, strategi termasuk teori belajar dan lain sebagainya. Kesemua persiapan tersebut harus dirancang sebaik mungkin sesuai dengan porsinya masingmasing. Teori belajar merupakan bagian penting dalam pelaksanaan pembelajaran, karena teori belajar akan dihadapi setiap harinya oleh pendidik dan peserta didik. Tidak semua teori belajar relevan dan dapat diimplementasikan dalam pembelajaran, ada beberapa hal atau cakupan yang harus disesuaikan sebelum menerapkan teori belajar. Setiap teori mempunyai porsi kelebihan dan 
kekurangannya masing-masing. Belajar memiliki definisi serta sudut pandang yang banyak dan berbeda-beda. Untuk dapat mengetahui relevan atau tidaknya suatu teori belajar tentu perlu diterapkan secara langsung disekolah. Satu diantara teoriteori yang wajib dan sudah lazim digunakan di Indonesia adalah Teori Belajar Kognitif . Teori belajar kognitif salah satu teori yang sering diterapkan di sekolah-sekolah. Salah satunya di Sekolah Islam Terpadu (SIT) Bina Insan Batang Kuis. Sebagai salah satu sekolah yang familiar di kota Medan, penulis tertarik untuk mengetahui bagaimana proses penerapan teori belajar kognitif pada mata pelajaran PAI tingkat SMP di SIT Bina Insan Batang Kuis.

\section{Metode}

Metode penelitian yang penulis gunakan adalah metode penelitian kualitatif. Metode penelitian kualitatif digunakan untuk meneliti obyek pada kondisi alamiah (naturalistik) yang berkembang apa adanya tanpa adanya manipulasi data dari peniliti. (Sugiyono, 2008, p. 15). Objek kajian penelitian terfokus pada analisa buku, dan penelitianpenelitian ilmiah seperti jurnal. Berhubung penelitian dilakukan ditengah pandemi Covid 19, dan sekolah-sekolah masih melaksanakan pembelajaran jarak jauh (daring), maka penulis hanya mewawancarai langsung salah seorang pendidik yaitu Wahyuni Apriliani Dasopang selaku Guru Pendidikan Agama Islam tingkat SMP di Sekolah Islam Terpadu Bina Insan sebagai teknik pengumpulan data. Lokasi sekolah berada di Batang Kuis Kabupaten Deli Serdang Sumatera Utara. Selanjutnya data-data tersebut penulis kaji serta analisis menggunakan studi pustaka dan penelitian ilmiah yang relevan. Penulis melakukan wawancara dengan informan menggunakan paltform WhatsApp. Wawancara yang dilakukan sebagai bukti nyata terhadap informasi maupun keterangan yang diperoleh oleh penulis dengan sebenarbenarnya di lapangan tanpa ada penyelewengan data. (Juliansyah, 2011, p. 139).

\section{Hasil dan Pembahasan \\ A. Pengertian Teori Belajar Kognitif}

Secara bahasa Istilah "Cognitive" berasal dari kata cognition artinya adalah pengertian, mengerti. Teori kognitf awal mulanya dikemukakan oleh Dewwy, dilanjutkan oleh Jean Piaget, Kohlberg, Damon, Mosher, Perry dan lain-lain, yang membicarakan tentang perkembangan kognitif dalam kaitannya dengan belajar. Kemudian dilanjutkan oleh Jerome Bruner, David Asubel, Chr. Von Ehrenfels Koffka, Kohler, Wertheimer dan sebagainya. (Sutarto, 2017, p. 2). Teori kognitif dikembangkan oleh Jean Piaget, ia lahir pada tahun 1896-1980 di Swiss sebagai seorang psilolog. Dalam psikologi perkembangan, teorinya memberikan banyak konsep utama dan berpengaruh terhadap perkembangan konsep kecerdasan. Teori ini membicarakan munculnya schemata (skema bagaimana seseorang mempersepsikan lingkungannya) dan bagaimana ia diperoleh yakni dalam jenjang perkembangan dan saat seseorang mendapatkan cara baru dalam merepresentasikan informasi secara mental. Teori ini termasuk ke dalam golongan konstruktivisme, bukan sebagai teori nativisme yang mengilustrasikan perkembangan kognitif sebagai awal munculnya pengetahuan dan kemampuan bawaan. Teori kognitif menganggap bahwa manusia membangun kemampuan kognitifnya melalui tindakan yang termotivasi dengan sendirinya terhadap lingkungan. Tujuan aspek kognitif mengarah pada kecakapan pola pikir yang meliputi kesederhanaan intelektualitas berupa daya ingat, selanjutnya kecakapan dalam menanggulangi permasalahan guna membiasakan peserta didik agar mampu menghubungakan dan menggabungkan beberapa ide, gagasan, persepsi, metode atau prosedur yang dipelajari untuk menyelesaikan masalah tersebut. (Tony, 
2018, p. 14). Kecakapan tersebut diharapkan dapat dimiliki oleh peserta didik secara keseluruhan. Melalui pengalaman yang dimiliki, peserta didik dapat menganalisa serta menyelesaikan permasalahan yang ia alami.

Dalam pandangan kognitif belajar tidak senantiasa hanya berupa perubahan tingkah laku yang dapat diamati saja. Dugaan awal teori ini adalah setiap individu telah memiliki pengalaman dan pengetahuan dalam dirinya. Pengalaman dan pengetahuan tersebut terstruktur dalam format struktur kognitif. Menurut teori ini, proses belajar akan sejalan dengan harapan jika materi pelajaran yang baru beradaptasi dengan struktur kognitif yang telah dimiliki oleh peserta didik (Thobroni, 2015, p. 79). Belajar sebagai perubahan persepsi dan pemahaman, yang tidak selalu dapat terlihat sebagai tingkah laku. Bagianbagian situasi tertentu saling keterkaitan dengan konteks seluruh situasi menjadi gagasan utama teori ini. Belajar merupakan proses internal yang meliputi: ingatan, retensi, pengolahan informasi, emosi dan faktor-faktor lain. (Fairuz dan Umi, 2019, p. 97). Ciri khas belajar kognitif terletak dalam belajar guna mencapai dan mempergunakan bentuk-bentuk representatif yang mewakili obyek-obyek yang di representasikan atau dihadirkan melalui tanggapan, gagasan atau lambang, dalam diri seseorang yang semuanya bersifat mental. (Nurhadi, 2020, p. 83). Teori belajar kognitif lebih menitikberatkan kepada proses belajar, seseorang belajar untuk membangun pengetahuan dalam dirinya secara continue dengan interaksi melalui lingkungan disekitarnya. Proses tersebut terus mengalir, menyeluruh dan terus bersambung dan berkembang tidak terputus-putus dan terus berjalan sepanjang ia terus belajar (Thobroni, 2015, p. 80).

Teori kognitif menekankan belajar sebagai aktivitas mental yang terjadi dan terbentuk dengan sendirinya di dalam kognisi si belajar. Kekayaan fenomena lingkungan menyediakan objek-objek untuk diamati, seperti simpulan Schunk bahwa social cognitive learning theory conteds that people learn form their social environments. Prinsip utama belajar menurut paradigma kognitif adalah keberhasilan belajar akan tampak apabila adanya penyesuaian materi, strategi, atau media yang digunakan pendidik terhadap perkembangan kognitif si peserta didik melalui pengalamannya. Hal ini mengindikasikan bahwa pembelajaran dirancang sesuai kebutuhan peserta didik (Frimina, 2017, p. 107). Dari beberapa teori diatas, penulis dapat menyimpulkan bahwa teori belajar kognitif adalah proses berpikir dengan berbagai kondisi mental yang di alami peserta didik untuk memecahkan permasalahan yang dialami melalui pengalaman-pengalaman serta interaksinya dengan lingkungan sekitarnya.

\section{B. Penerapan Teori Belajar Kognitif Pada Mata Pelajaran PAI Tingkat SMP di Sekolah Islam Terpadu Bina Insan Batang Kuis}

Sekolah Islam Terpadu Bina Insan Batang Kuis berdiri sejak Tahun 2013. Sekolah ini beralamat di Medan Kecamatan Batang Kuis Kabupaten Deli Serdang, Sumatera Utara. Selaku salah satu dari sekolah ternama, sekolah berbasic IT ini sudah menggunakan kurikulum 2013 sejak beberapa tahun belakangan silam. Wahyuni Apriliani Dasopang selaku guru PAI tingkat SMP di SIT Bina Insan tentu sudah khatam mengenai penerapan kurikulum 2013. Salah satu bagian yang tak asing baginya adalah teori belajar. Melalui pengalamannya sebagai pendidik, ia sudah bereksperimen dengan berbagai teori-teori belajar. Dalam penggunaan teori belajar ada beberapa hal yang harus diperhatikan, yaitu terkait pemilihan materi, pengembangan materi dan juga rancangan pembelajaran yang di buat dengan semaksimal mungkin agar mempermudah peserta didik dalam memahami materi pelajaran. Keberhasilan proses belajar mengajar tidak sekedar terukur secara tekstual saja, namun dapat 
dilihat dengan terwujudnya perilaku positif yang santun lagi baik dari peserta didik (Fadhil dan Suyadi, 2020, p. 96).

Wahyuni Apriliani Dasopang menuturkan bahwa ia cukup sering menggunakan teori-teori belajar, salah satunya diantaranya adalah teori belajar kognitif. Wahyuni mengatakan bahwa teori belajar ini memiliki kesinambungan antara satu tokoh dengan tokoh kognitif lainnya, menurutnya teori dari tokoh-tokoh tersebut dapat digunakan dan diterapkan dalam satu kali proses pembelajaran, ia menjelaskan bahwa pada dasarnya semua berawal dan mengacu pada teori dari Jean Pieget untuk bisa mengetahui tahapan perkembangan peserta didik. Dalam teori ini tujuannya adalah peserta didik bisa mengubah pandangan subyektifnya menjadi pandangan obyektif atas suatu permasalahan yang melatih peserta didik untuk bisa berargumen dari pemahaman materi yang dia sudah dapatkan melalui pembelajaran. Lebih lanjut wahyuni menjelaskan bahwa ia juga menerapkan teori belajar kognitif dari Jerome Bruner, dimana teori Bruner menekankan peserta didik untuk bisa menjadi partisipasi aktif, sedangkan pendidik memantau dan memotivasi peserta didik serta memfasilitasi dan mengevaluasi hasil pembelajaran mereka. Bruner menggaris bawahi bahwa proses belajar akan berjalan sempurna sesuai dengan tujuan, jika pendidik menyerahkan kepada peserta didik keleluasaan untuk mencari dan menemukan suatu pemahaman, aturan, konsep, atau teori melalui hal-hal atau pengalaman yang ia temui dalam kehidupannya sehari-hari dengan beraneka ragam sumber yang ada (Tutik dan Daryanto, 2015, p. 64). Selanjutnya Wahyuni juga menerapkan teori Ausubel dalam proses pembelajaran, pada teori Ausabel pendidik ditekankan untuk bisa memilih metode dan strategi mengajar, menggunakan media pembelajaran yang bisa membuat peserta didik mendapatkan pembelajaran bermakna sehingga membuat peserta didik memiliki antusias yang tinggi serta motivasi untuk belajar. Menurut Ausubel belajar bermakna dapat diwujudkan jika peserta didik memiliki persiapan yang matang untuk belajar disertai minat yang kuat. Maka dari itu pendidik dituntut mampu menciptakan pembelajaran yang bermakna dan menyenangkan agar timbulnya motivasi belajar peserta didik ketika proses pembelajaran (Sutarto, 2017, p. 18). Kebermaknaan yang dimaksud ialah peserta didik memiliki respon serta antusias yang tinggi untuk mengikuti proses pembelajaran. Pembelajaran yang dimaksud fokus dengan adanya keterkaitan antara materi yang telah dipelajari sebelumnya dengan materi yang akan di ajarkan. Hubungan antara materi tersebut sebagai kunci pembelajaran yang dikatakan baik. Materi-materi tersebut selanjutnya akan dijabarkan dan dipersentasikan dengan baik oleh pendidik (Hidayatul dan Suyadi, 2020, p. 168).

Kemudian Wahyuni mengatakan bahwa ia juga menggunakan teori Gestalt yaitu bagaimana peserta didik belajar bukan hanya dengan menghafal atau dalam arti peserta didik tidak paham, melainkan dengan teori ini peserta didik mampu berfikir kritis sehingga mampu menganalisis serta mampu mengungkapkan argumen atas permasalahan yang di alami dari apa yang telah ia pahami melalui insight (pemahamannya). Teori gestalt menganggap belajar sebagai proses memahami dan mengamati suatu hubungan-hubungan antar bagian dalam suatu kondisi problem. Seseorang dijuluki sukses dalam belajar ketika ia berani menghadapi dan mengerti permasalahan yang ia hadapi dan ia mampu menyelesaikannya dengan pemahaman (insight) yang ia punya (Yossita, 2020, p. 211). Melalui penuturan Wahyuni dapat disimpulkan bahwa teori-teori kognitif dari tokoh-tokoh kognitivisme dapat diterapkan sejalan bersamaan dalam proses pembelajaran, artinya teori-teori tersebut sinkron dan saling berkesinambungan 
karena memiliki tujuan yang selaras walaupun di terapkan sekaligus. Namun yang perlu digaris bawahi adalah pembelajaran tersebut akan berhasil jika pendidik dapat merancang komponen pembelajaran seperti metode, strategi dan media dengan baik, sehingga terciptanya kondisi belajar yang menyenangkan serta bermakna bagi peserta didik.

Penerapan teori belajar kognitif yang dilakukan Wahyuni bukan kali pertama ia gunakan. Hampir di beberapa materi pembelajaran ia menerapkannya, karena tujuan dari Kurikulum 2013 sejalan dengan teori belajar kognitif. Proses pembelajaran Kurikulum 2013 menekankan jika peserta didiklah yang menjadi subjek belajar, sedangkan pendidik hanya memotivasi dan memfasilitasi serta menjadi salah satu sumber belajar bagi mereka. Sumber belajar yang digunakan bersifat fleksibel dan bervariasi artinya tidak terfokus pada satu sumber belajar saja, peserta didik dapat menggali berbagai informasi, ilmu pengatahuan serta wawasan melalui buku bacaan, pengalaman, guru, orangtua, internet dan sumber-sumber belajar lainnya, sehingga hasil yang didapatkan selama pembelajaran dapat berkembang terus menerus sesuai dengan minat dan kebutuhan peserta didik (Suyadi dan Dahlia, 2014, p. 24). Sama halnya dengan teori belajar kognitif, yang mengharuskan pembelajaran aktif dan berpusat pada peserta didik agar mereka mampu berfikir untuk mengasah kognitifnya, dan tidak hanya paham secara teoritik saja melainkan paham dan mampu mengamati secara langsung dilingkungan sekitarnya serta melaksanakannya dalam kehidupan seharihari. Itulah salah satu alasan mengapa teori belajar kognitif menjadi teori yang populer dan sering digunakan di Indonesia, karena tujuan dari teori ini sejalan dengan Kuirkulum 2013 yang bermuara pada peserta didik yang dituntut untuk aktif. Dalam pandangan kognitivisme, belajar diartikan sebagai perubahan informasi atau ilmu pengetahuan yang ada dilingkungan, selanjutnya diserap dalam pikiran kemudian diaplikasikan melalui tindakan dilapangan. Terjadinya belajar saat pengetahuan baru didaptkan atau pengetahuan lama diubah oleh pengalaman-pengalaman (Baharuddin dan Elsa, 2015, p. 126). Pengalaman menentukan keberhasilan proses belajar peserta didik, melalui pengalamanpengalaman tersebut peserta didik diharapkan mampu mengambil pelajaran yang positif dan menjadikannya sebagai tolak ukur keberhasilan dimasa mendatang.

Lebih lanjut Wahyuni menjelaskan bagaimana ia menerapkan teori belajar kognitif. Sebagai contoh materi yang diambil adalah materi beriman kepada qadha dan qadhar, pertama ia membuka pembelajaran dengan memberitahukan materi dan alasan materi tersebut dipelajari kemudian ia menjelaskan materi sedikit dengan menuliskan di papantulis dengan peta konsep, setelah itu ia berlakukan metode tanya jawab. Konsep pembelajaran kognitif berpengaruh besar pada pembelajaran yang berupa pemberian kesadaran tinggi kepada pendidik betapa pentingnya pengaruh pengetahuan awal (entry behavior) dan strategi penguatan memori siswa terhadap pembelajarannya saat ini (Mohammad, 2015, p. 225). Setelah mereka paham ia menyajikan untuk setiap kelompok cerita yang sudah ia dapatkan dari internet yang berkaitan dengan beriman kepada qadha dan qadhar. Kemudian masing-masing kelompok memiliki tugas mencari dan menganalisis cerita dengan materi beriman kepada qadha dan qadhar, setelah itu para peserta didik memaparkan temuan analisanya di depan kelas menghadap teman-temannya dan memberikan kesempatan kepada kelompok lain untuk bertanya perihal materi yang sudah mereka sampaikan. Kemudian di kelas VIII sebagai contohnya adalah materi beriman kepada kitab-kitab Allah SWT, proses pembelajarannya sama dengan kelas VIII hanya saja mereka dibagi dalam 4 kelompok sesuai 4 kitab yang mereka pelajari, kemudian Wahyuni memberikan 
beberapa soal untuk mereka jawab yang berkaitan dengan materi, di pertemuan berikutnya untuk mengevaluasi pemahaman mereka ia membuat card (kartu) yang berisi pertanyaan dan card (kartu) yang berisi jawaban, kemudian ia bagikan kepada peserta didik secara acak kemudian mereka dipanggil satu nama dari absen untuk membacakan satu kartu yang ia dapatkan dan yang merasa mendapatkan pertanyaan atau jawaban dari temannya si peserta didik berdiri dan membacakan kartunya. Jika benar mendapatkan poin dan yang salah mendapatkan pengurangan nilai. Di akhir pembelajaran Wahyuni meminta tiga orang yang bersedia untuk menjelaskan apa yang telah ia pahami atau ilmu apa saja yang ia ingat dari kartu-kartu yang sudah dipasangkan dengan jawaban dihadapan teman-temannya, jika jawabannya sesuai dengan materi yang telah dipelajari, maka peserta didik tersebut akan mendapatkan poin atau tambahan nilai darinya. Sedangkan di kelas VII wahyuni pernah menggunakan media gambar dan silsilah Nabi Muhammad SAW secara sederhana dengan kertas karton yang ditempelkan di papan tulis, ia juga pernah menggunakan power point saat materi Dakwah Rasulullah di Mekkah. Begitulah proses pembelajaran yang ia lakukan, Wahyuni juga menuturkan bahwa ia juga pernah melakukannya di kelas VIII saat materi pembelajaran secara keseluruhan sudah selesai. Mereka diberikan menonton film Muhammad AlFatih kemudian mereka analisis ilmu yang sudah mereka dapatkan dari sosok Muhammad al-Fatih dengan menjawab 10 pertanyaan yang ia berikan kepada mereka dan hampir keseluruhan mereka bisa menjawab pertanyaan tersebut dengan baik sesuai dengan apa yang telah mereka saksikan dari film tersebut.

Melaluieksperimennya

menggunakan teori belajar kognitif, ternyata memberikan hasil yang positif. Penerapan teori belajar kognitif memberikan hasil yang cukup memuaskan pada jenjang SMP PAI di kelas yang
Wahyuni ajar, hal tersebut terbukti dengan jawaban dari soal-soal (ulangan atau ujian) dan presentasi peserta didik ketika ujian nilainya melewati KKM (Kriteria Ketuntasan Minimal). Hal ini membuktikan bahwa penerapan teori belajar kognitif cukuplah efektif. Efektivitas hasil pembelajaran terjadi jika adanya perubahan yang positif berupa tingkah laku, kemudian tujuan pembelajaran yang dirancang tercapai sesuai rencana yang telah ditetapkan. Proses pembelajaran yang berhasil dan berbobot tercipta apabila pendidik menerima segala kritik serta saran yang membangun dari semua kalangan, sebagai orang yang berpendidikan, tentu pendidik harus bisa menerima segala masukan tanpa menutup telinga terhadap kritik-kritik guna perubahan menuju ke arah yang lebih baik, agar hasil yang diperoleh melewati standar atau target yang telah di planning (Ahmad, 2013, p. 54). Wahyuni menuturkan jika feedback yang ia tuai dari peserta didik ketika diterapkannya teori belajar kognitif sangat sesuai dengan harapannya. Mereka mampu mengungkapkan kembali materi dan contoh yang sudah mereka temukan di lingkungannya. Efektifnya suatu pembelajaran merupakan barometer kesuksesan pendidik dalam menguasai dan mengelola kelas. Keterlibatan peserta didik secara aktif baik mental, fisik, maupun sosialnya merupakan bagian dari efektifnya suatu proses pembelajaran. Karena atkivitas peserta didiklah yang diharapkan dominan selama proses pembelajaran berlangsung. Pembelajaran berkualitas bisa dinilai melalui sudut pandang progres serta dari hasil yang didapat. Jika ditanya seberapa efektif teori belajar kognitif diterapkan, Wahyuni mengatakan bahwa teori belajar kognitif yang ia terapkan efektif dengan persentasi diatas $70 \%$. Artinya teori ini dapat diandalkan untuk mewujudkan pembelajaran yang bermakna bagi peserta didik. Menurutnya teori belajar kognitif efektif untuk diterapkan dijenjang SMP PAI karena peserta didik bisa mendapatkan 
pemahaman dari berbagai strategi mengajar yang diterapkan dan bisa mendapatkan beberapa gambar dari media pembelajaran yang juga pernah ia sajikan, dalam materi Sejarah Kebudayaan Islam misalnya yakni materi Dakwah Rasulullah SAW di Mekah dan Madinah, meneladani dari Sifat Sahabat Nabi yakni Khulafurrasyidin, dan materi lainnya. Hanya saja ia harus bisa menyesuaikan dengan jenjang peserta didiknya. Dimana untuk kelas VII ia mengatakan jangan terlalu memberikan persoalan yang terlalu tinggi atau materi yang sulit untuk ditangkap oleh peserta didik, karena hal tersebut dapat membuat peserta didik sulit memahaminya, sedangkan tingkatan menengah untuk kelas VIII dan agak sulit untuk kelas IX sekaligus melatih mereka dengan materi di kelas VII dan VIII untuk mengulangi pemahaman mereka saat ada waktu luang setelah memahami materi yang harus mereka pelajari di kelas IX.

Setiap sesuatu pasti memiliki nilai plus dan minus. Wahyuni mengungkapkan bahwa teori ini memiliki kelebihan dan kekurangan. Melalui pengalamannya selama menerapkan teori belajar kognitif, ia menemukan beberapa kelebihan dan kekurangan. Pertama, kelebihan teori ini setelah ia terapkan adalah anak-anak menjadi lebih berfikir kritis serta analistik atas apa yang mereka kerjakan, mereka dapat memahami materi dan contoh melalui hasil analisis, pengamatan dan pemahaman yang mereka kerjakan. Kelebihan selanjutnya adalah tumbuhnya kemandirian serta meningkatnya kreativitas peserta didik, mereka akan marasa bertanggungjawab atas apa yang mereka kerjakan, melalui teori kognitif mereka akan terbiasa terlatih untuk berpikir secara matang, mereka tidak merasa sulit untuk memahami pelajaran yang mereka terima. Sedangkan untuk kekurangan yang ia alami berdasarkan pengalamannya adalah yang pertama terkait proses pembelajaran akan sedikit memakan waktu yang lebih lama dengan alokasi waktu yang terbatas. Tentu hal ini menjadi catatan baginya, karena semua materi yang terjadwal harus tersampaikan secara keseluruhan sebelum tiba waktunya ujian. Dalam mengatasi hal ini, Wahyuni berusaha memaksimalkan metode, strategi serta media yang ia ajar agar dapat terancang dengan sebaik mungkin sesuai dengan kebutuhan. Kemudian kekurangan lain yang ia alami adalah tidak semua teori dan tingkat pendidikan dapat di praktikkan menggunakan teori kognitif, ada beberapa materi yang pemahamannnya sulit jika menggunakan teori belajar kogntif. Dalam hal ini Wahyuni mengganti teori belajar kognitif dengan teori belajar lainnya yang relevan dengan tingkat materi dan peserta didiknya. Ia juga mengalami kesulitan saat memahamkan kepada peserta bagaimana proses kerja kelompok sebagai salah satu strategi yang ia gunakan. Perihal kesulitan tersebut ia harus mengulang penjelasannya sampai peserta didik benar-benar paham betul bagaimana proses atau alur pembelajaran yang dimaksud, sehingga proses belajar akan berjalan kondusif dan efesien yang nantinya akan menghasilkan output yang sesuai dengan harapan

\section{Kesimpulan}

Setelah dilakukan penelitian ternyata penerapan teori belajar kognitif pada Mata Pelajaran PAI Tingkat SMP di Sekolah yang penulis teliti cukup efektif dengan pesertanse diatas $70 \%$. Hal tesebut dibuktikan dengan nilai ujian peserta didik melewati dari KKM (Kriteria Ketuntasan Minimal). Efektivitas tersebut menjulang sukses tentu karena Wahyuni Apriliani Dasopang selaku pendidik Mata Pelajaran PAI di SIT Bina Insan mempersiapkannya dengan matang, baik dari segi metode, startegi, media dan tentu didukung dengan teori belajar dari beberapa tokoh dari kognitif. Dari beberapa teori dari tokoh kognitivisme memiliki tujuan yang sejalan, sehingga teori-teori ini dapat digabungkan bersamaan untuk diaplikasikan dalam proses pembelajaram. Walaupun teori belajar kognitif memiliki kukurangan tapi tidak membuat teori belajar ini lantas tidak efektif untuk diterapkan. Apalagi teori ini 
cukup populer dan sering diterapkan di sekolah-sekolah, karena teori ini menunut proses berpikir peserta didik agar dapat mengasah dan meningkatkan kognitifnya melalui pengalaman-pengelaman selama proses pembelajaran yang dilaluinya.

\section{Daftar Pustaka}

[1] Angela, Frimina Nai. (2017). Teori Belajar dan Pembelajaran Impelementasinya dalam Pembelajaran Bahasa Indonesia di $S M P, S M A$, dan SMK. Yogyakarta: Deepublish.

[2] Ansyar, Mohammad. (2015). Kurikulum ; Hakikat, Fondasi, Desain dan Pengembangan. Jakarta: Kencana.

[3] Aqib, Zainal dan Ahmad Amrullah. (2019). Manajemen belajar dan pembelajaran di Sekolah. Yogyakarta: Rustaka Referensi.

[4] Baharuddin dan Elsa Nur Wahyuni. (2015). Teori Belajar dan Pembelajaran. Yogyakarta: Ar-Ruzz Media.

[5] Fadhil Muhammad, Alghi Fari Majid dan Suyadi. (2020). Penerapan Teori Belajar Behavioristik dalam Pembelajaran PAI. Jurnal Ilmiah Bimbingan dan Konseling, 1 (3), 96.

[6] Hartanto, Tony dkk. (2018). Perbandingan Capaian Hasil Belajar Kognitif Siswa Pada Penerapan Metode Pembelajaran Student Facilitator And Explaining Pada 4 (Empat) Kategori Mata Pelajaran Produktif. IJCEE, 4 (1), 9-24.

[7] Karya, Wayan. (2017). Asumsi Dasar Teori Kognitif, Behavioristik dan Humanistik." Jurnal Bawi Ayah, 8 (2), 40-48.

[8] Muamanah, Hidayatul dan Suyadi. (2020). Pelaksanaan Teori Belajar Bermakna David Ausubel Dalam Pembelajaran Pendidikan Agama Islam. Jurnal Pendidikan IslamBelajea, 5 (1), 23-36. DOI:10.29240/belajea.v5

[9] Noor, Juliansyah. (2011). Metode Penelitian; Skripsi, Tesis, Disertasi, dan Karya Ilmiah. Jakarta: Kencana.
[10] Nurhadi. (2020). Teori Kognitivisme Serta Aplikasinya Dalam Pembelajaran. Jurnal Edukasi dan Sain, 2 (1), 77-95.

[11] Rachmawati, Tutik dan Daryanto. (2015). Teori Belajar dan Proses Pembelajaran yang Mendidik. Yogyakarta: Gava Media.

[12] Rosyid, M. Fairuz dan Umi Baroroh. (2019). Teori Belajar Kognitif dan Implikasinya Dalam Pembelajaran Bahasa Arab. Lisanuna, 9 (1), 92-110. http://dx.doi.org/10.22373/ls.v9i1.673 5

[13] Rusman. (2017). Belajar dan Pembelajaran ; Berorientasi Standar Proses Pendidikan. Jakarta: Kencana.

[14] Sholihah, Rifqiyyatush Al-Mahiroh dan Suyadi. (2020). Kontribusi Teori Kognitif Robert M. Gagne dalam Pembelajaran Pendidikan Agama Islam. Jurnal Pendidikan, Sosial dan Agama-Qalamuna, 12 (2), 117-126. https://doi.org/10.37680/qalamuna.v12 i2.353

[15] Sugiyono. (2008). Metode Penelitian Pendidikan; Pendekatan Kuantitatif, Kualitatif dan $R \& D$ Bandung: Alfabeta.

[16] Susanto, Ahmad. (2013). Teori belajar dan Pembelajaran di sekolah dasar. Jakarta: Kencana.

[17] Sutarto. (2017). Teori kognitif dan implikasinya dalam pembelajaran. Islamic Counseling, 1 (2), 1-26. http://dx.doi.org/10.29240/jbk.v1i2.33 1

[18] Suyadi dan Dahlia. (2014). Implementasi dan Inovasi Kurikulum PAUD 2013. Bandung: Remaja Rosdakarya.

[19] Thobroni, M. Belajar dan Pembelajaran; teori dan praktik. Yogyakarta: Ar-Ruzz Media.

[20] Wisman, Yossita. (2020). Teori Belajar Kognitif Dan Implementasi Dalam Proses Pembelajaran. Jurnal Ilmiah Kanderang Tingang. 11 (1). 209-215. https://doi.org/10.37304/jikt.v11i1.88 
Profil Penulis 1

Muhammad Alpin Hascan lahir di kota Medan tahun 1997. Pendidikan sarjana diselesaikan di UIN Sumatera Utara Prodi Pendidikan Agama Islam pada tahun 2019 silam. Saat ini sedang aktif kuliah pascasarjana di UIN Sunan Kalijaga Yogyakarta Prodi Pendidikan Agama Islam.

Profil Penulis 2

Suyadi lahir pada tahun 1977 menyelesaikan Studi Sarjananya di Universitas Muhammadiyah Yogyakarta Prodi Pendidikan Agama Islam, kemudian di Universitas yang sama menyelesaikan Studi Islam Pascasarjananya dan melanjutkan Studinya s3 di Universitas Negeri Malang Prodi Psikologi Pendidikan dan saat ini akitf menjadi dosen dibeberapa Universitas di Yogyakarta. 